\title{
EFFECT OF KARANGNUNGGAL BENTONITE ADDITION ON THE MECHANICAL STRENGTH OF CONVENTIONAL CERAMICS
}

\author{
PENGARUH PENAMBAHAN BENTONIT KARANGNUNGGAL \\ TERHADAP KEKUATAN MEKANIK KERAMIK KONVENSIONAL
}

\author{
WIDODO $^{1}$, SOLIHIN ${ }^{1}$ and SUBARI ${ }^{2}$ \\ ${ }^{1}$ Research Centre for Geotechnology, LIPI \\ Kompleks LIPI, Jalan Sangkuriang Bandung 40135, Indonesia \\ widodo@geotek.lipi.go.id, widodohadiseputro@gmail.com \\ ${ }^{2}$ Centre for Ceramics, Ministry of Industry \\ Jalan Jenderal Achmad Yani No. 392 Bandung 40272, Indonesia
}

\begin{abstract}
Bentonite can be used as an additive in ceramics production. It can increase the thermal resistance and flexural strength of ceramics. Indonesia has a large amount of bentonite deposit. One of them is located in Karangnunggal, Tasikmalaya. The aim of this research is to study the effect of bentonite to increase the flexural strength of ceramic. The raw materials consisting of kaolin, feldspar, and quartz were used as raw materials in ceramics production. The weight percents of kaolin and quartz were fixed at $55 \%$ and $20 \%$, whereas weight percents of feldspar and bentonite were varied at $25 \%, 20$ $\%, 15 \%, 10 \%$ and $0,5 \%, 10 \%, 15 \%$. The firing temperature was kept at $1,200{ }^{\circ} \mathrm{C}$. Result of the experiment shows that the best composition to achieve the highest dry flexural strength at 254.70 $\mathrm{kg} / \mathrm{cm}^{2}$ is at $55 \%$ kaolin, $20 \%$ quartz, $15 \%$ feldspar, and $10 \%$ bentonite.
\end{abstract}

Keywords: bentonite, additive, ceramics, flexural

\begin{abstract}
ABSTRAK
Bentonit dapat digunakan sebagai bahan aditif dalam produksi keramik. Material ini dapat meningkatkan ketahanan panas dan kekuatan lentur keramik. Indonesia memiliki deposit bentonit dalam jumlah besar, Salah satunya terletak di Karangnunggal, Kabupaten Tasikmalaya. Tujuan penelitian ini adalah mempelajari pengaruh bentonit untuk meningkatkan kekuatan lentur keramik. Bahan baku yang terdiri dari kaolin, felspar, dan kuarsa digunakan sebagai bahan baku dalam produksi keramik. Persen berat kaolin dan kuarsa ditetapkan sebesar $55 \%$ dan $20 \%$, sedangkan \% berat felspar dan bentonit masing-masing divariasikan sebesar $25 \%, 20 \%, 15 \%, 10 \%$ dan 0,5\%, 10 $\%, 15 \%$. Pembakaran dilakukan pada temperatur $1.200{ }^{\circ} \mathrm{C}$. Hasil penelitian menunjukkan bahwa komposisi terbaik untuk mencapai kekuatan lentur bakar tertinggi pada $254,70 \mathrm{~kg} / \mathrm{cm}^{2}$ adalah $55 \%$ kaolin, $20 \%$ kuarsa, $15 \%$ felspar, dan $10 \%$ bentonit.
\end{abstract}

Kata kunci: bentonit, aditif, keramik, lentur

\section{INTRODUCTION}

Bentonite is classified as a hydrated clay in the colloid form. It mainly consists of montmorillonite $\left(\mathrm{Al}_{2}, \mathrm{Mg}_{3}\right)\left(\mathrm{Si}_{4} \mathrm{O}_{10}\right)(\mathrm{OH})_{2} \cdot \mathrm{nH}_{2} \mathrm{O}$, which is the layer of $\left(\mathrm{SiO}_{4}\right)^{2+}$ tissues with its ratio of $\mathrm{Si} / \mathrm{O}$ is equal to 2/5, (Rowe, Sheskey and Quinn, 2009). Besides montmorillonite, the bentonite also consists of other minerals such as illite $\left\{\left(\mathrm{K}, \mathrm{H}_{3} \mathrm{O}\right)(\mathrm{Al}, \mathrm{Mg}, \mathrm{Fe})_{2}(\mathrm{Si}, \mathrm{Al})_{4} \mathrm{O}_{10}(\mathrm{OH})_{2},\left(\mathrm{H}_{2} \mathrm{O}\right)\right\}$, kaolinite $\quad\left\{\mathrm{Al}_{2} \mathrm{Si}_{2} \mathrm{O}_{5}(\mathrm{OH})_{4}\right\}$, halloysite $\left\{\mathrm{Al}_{2} \mathrm{Si}_{2} \mathrm{O}_{5}(\mathrm{OH}]_{4}\right\}$, quartz $\left(\mathrm{SiO}_{2}\right)$, calcite $\left(\mathrm{CaCO}_{3}\right)$, and pyrite $\left(\mathrm{FeS}_{2}\right)$ (Liu, Xie and Qin, 2017). In general, bentonite deposits are formed through rock weathering, reactions between rock with acidic hydrothermal 
solution, volcanic dust devitrification, and sedimentation from tufa deposition containing silica.

Two types of bentonite are known as sodium (sodic) bentonite and calcium (calcic) bentonite (Savic-Gajic et al., 2014; Boussak, Chemani and Aicha, 2015). The sodium bentonite contains more $\mathrm{Na}^{+}$ion than $\mathrm{Ca}^{2+}$ and $\mathrm{Mg}^{2+}$ ions. Expand bentonite in the water increases its viscosity. Potassium bentonite, which contains more potassium and magnesium (in the form of $\mathrm{K}_{2} \mathrm{O}$ and $\mathrm{MgO}$, respectively) absorbs less water so that it does not form a suspension.

Bentonite has been used in various sectors such as construction, environmental protection, electronic industry, agriculture, food processing, textile industry, soap production, biomedics, etc. (Savic et al., 2012, 2014; Boussak, Chemani and Aicha, 2015). In the ceramic industry, bentonite is usually mixed with another tuff such as clay, feldspar, and quartz to produce tiles, sanitary, tableware and decorative ceramics (Hosten and Cimilli, 2009). Composition of the soft ceramic is usually $25 \%$ of clay, $25 \%$ silica, and $50 \%$ sodium feldspar, whereas the composition of hard ceramic is $50 \%$ of clay, $25 \%$ silica and $25 \%$ potassium feldspar (Gualtieri, 2007; Boussak, Chemani and Aicha, 2015). Bentonite, clay, and silica are also often used as an additive reagent, binder, and filler (Djambazov, Yoleva and Malinov, 2009). Mixing and firing of those minerals at high temperature result in mullite formation, whereas the firing pure clay at $1000{ }^{\circ} \mathrm{C}$ results in a better mullitization process. On the other hand, clay firing of clay that contains mullite impurities can only be formed at a temperature above $1200^{\circ} \mathrm{C}$. (Septawendar, Nuryanto and Subari, 2007; Boussak, Chemani and Aicha, 2015).

The aim of this research is to evaluate the potential application of bentonite from Karangnunggal as an additive reagent to increase flexibility and pressure strength of the ceramics. The evaluation includes the analyses of mineral composition and chemical/physical property (dry shrinkage, firing shrinkage, dry flexural strength, thermal flexure, and water absorption).

\section{METHODOLOGY}

Research activities consist of sampling the bentonite, kaolin, feldspar, and quartz, whereas laboratory activities consist of bentonite characterization, ceramics preparing and product testing.

The minerals used in the experiment were bentonite, kaolin, feldspar, and quartz. Those were sampled from different locations in Indonesia. Bentonite, kaolin, and feldspar were obtained from Tasikmalaya, whereas quartz was taken from Sukabumi. The exact location of bentonite used in this study was Santrijaya Village, District of Karangnunggal, Tasikmalaya Regency, West Java Province ( $\left.\mathrm{S}=07^{\circ} 36^{\prime} 54.3^{\prime \prime} / \mathrm{E}=108^{\circ} 07^{\prime} 02.9^{\prime \prime}\right)$. The picture of the location is shown in Figure 1. The morphology of bentonite deposit was like a grayish white smooth lens. The bentonite was formed from breccia tuff. This tuff underwent alteration that leads to the diagenesis reaction to form bentonite (Figure 2).

The minerals were dried in an oven at 100 ${ }^{\circ} \mathrm{C}$ for 2 hours to reduce its moisture of the minerals. The dried minerals were ground and milled to attain a particle size of 150 mesh (100 microns). In order to reveal the additive property of the pure bentonite, the ground and milled bentonite were shaped and pressed to form a specimen with the size of $12 \mathrm{~cm} \times 1.5 \mathrm{~cm} \times 1 \mathrm{~cm}$, before being heated at $1,200{ }^{\circ} \mathrm{C}$ for 6 hours. The heated specimen was subjected to measurement of weight loss, stiffness, thermal stiffness, and the ability to absorb water. The composition of raw materials, which is based on the previous work by Boussak, Chemani and Aicha (2015), is shown in Table 1.

Meanwhile, other samples that consisted of bentonite and kaolin was milled in the pot mill for 6 hours, whereas feldspar and quartz were milled for 10 hours. The milled minerals were mixed, shaped and pressed to produce a specimen. The size of the specimen is $12 \mathrm{~cm} \times 1.5 \mathrm{~cm} \times 1 \mathrm{~cm}$. After being pressed, the specimen was dried at room temperature for seven days prior to firing at $1,200{ }^{\circ} \mathrm{C}$. The mechanical strength of the fired specimen was analyzed to reveal its mechanical strength and water absorption capacity. The flow sheet of ceramics preparation is shown in Figure 3. 


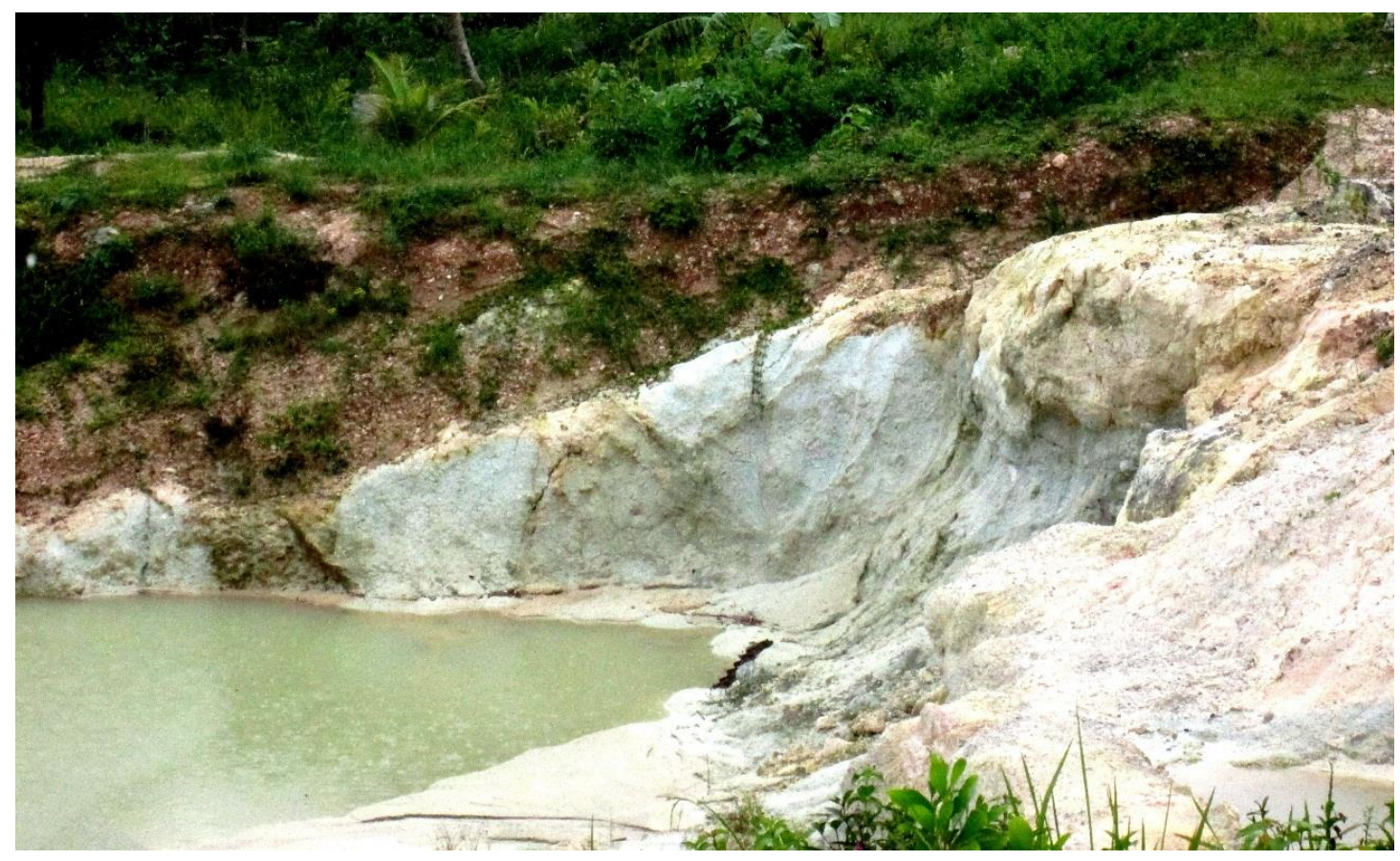

Figure 1. Bentonite deposit in Karangnunggal

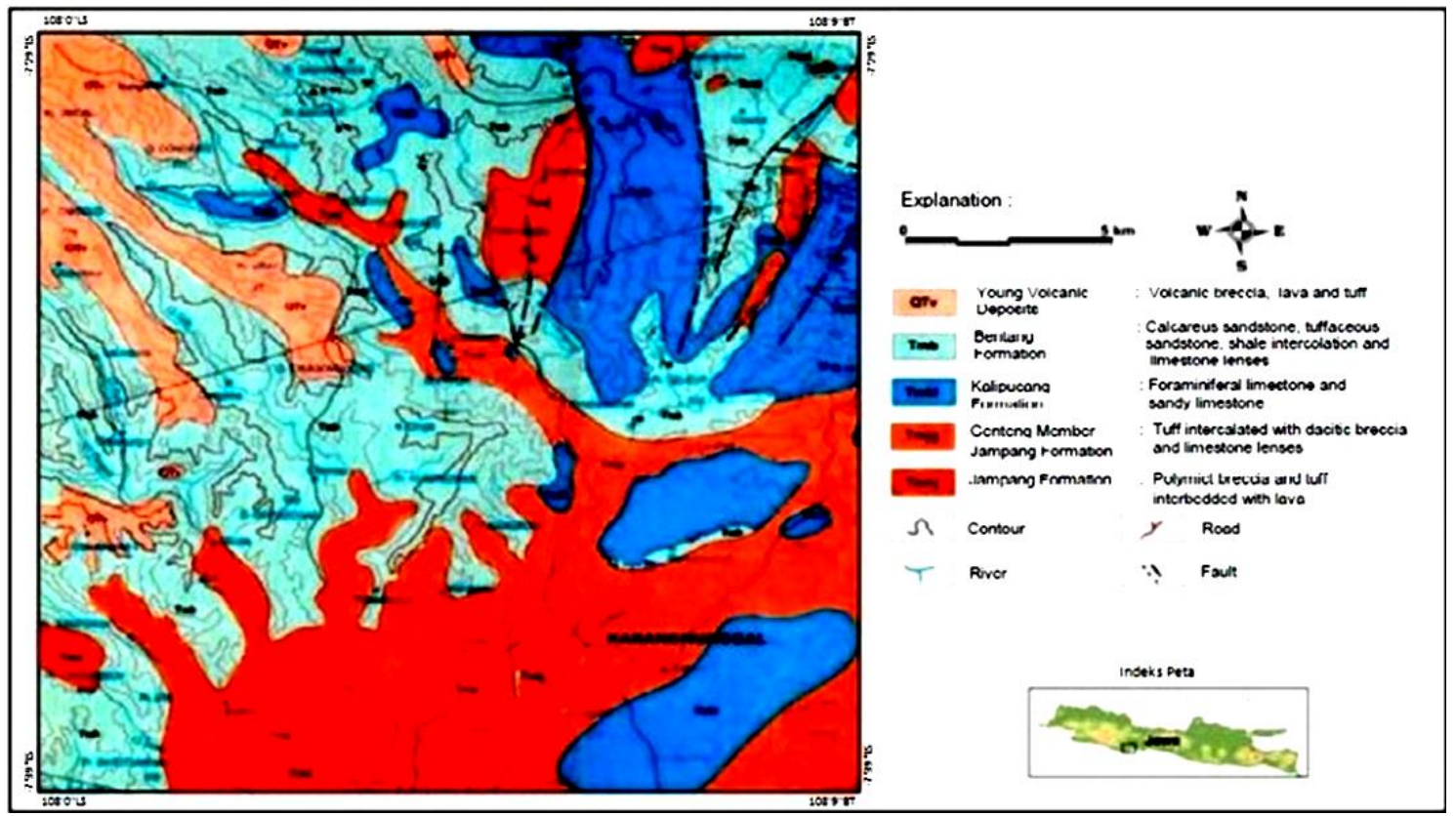

Figure 2. Geological map of Karangnunggal and surrounding area (Supriatna et al., 1992)

Table 1. Composition of ceramics

\begin{tabular}{ccccc}
\hline \multirow{2}{*}{ Minerals } & \multicolumn{4}{c}{$\%$ Weight } \\
\cline { 2 - 5 } & BC-0 & BC-1 & BC-2 & BC-3 \\
\hline Bentonite & 0 & 5 & 10 & 15 \\
Kaolin & 55 & 55 & 55 & 55 \\
Silica sand & 20 & 20 & 20 & 20 \\
Feldspar & 25 & 20 & 15 & 10 \\
\hline
\end{tabular}




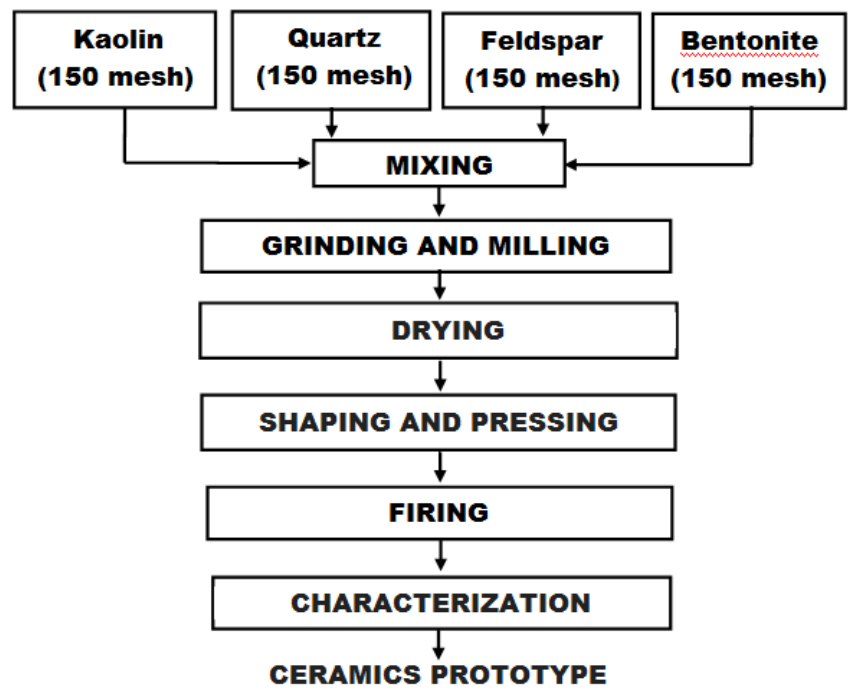

Figure 3. Flowsheet of ceramics prototype preparation

During the firing process, the dehydroxylation of kaolinite took place at $450{ }^{\circ} \mathrm{C}$. Then in the firing process up to $1,200{ }^{\circ} \mathrm{C}$, a reaction occurred between feldspar and quartz/silica and the formatted of mullite, respectively. The formatted of mullite contributed to the significant increase of the mechanical strength of the ceramics (Boch and Niepce, 2007).

The petrographic analysis was conducted through an optical microscope (Nikon Ipol-50) to observe the mineral composition of the bentonite. Scanning Electron Microscope Energy Dispersive X-Ray Spectroscopy (SEMEDX, Rigaku Japan) was applied to observe the bentonite morphology and to identify the minerals within the Karangnunggal bentonite. The exact minerals that composes bentonite were confirmed through XRD analysis (Shimazu, Japan). Chemical analysis was carried out on the raw materials using wet analysis method. The mineral was dissolved in aqua regia and the content of $\mathrm{Al}_{2} \mathrm{O}_{3}, \mathrm{Fe}_{2} \mathrm{O}_{3}$, $\mathrm{CaO}, \mathrm{TiO}_{2}$, and $\mathrm{MgO}$ in the resulted solution was analyzed using Atomic Absorption Spectroscopy (AAS, Shimazu, Japan). Meanwhile, the content of $\mathrm{SiO}_{2}, \mathrm{Na}_{2} \mathrm{O} / \mathrm{K}_{2} \mathrm{O}_{2}$ was analyzed through gravimetric method and flame photometer, respectively.

\section{RESULTS AND DISCUSSION}

Petrographic Analysis

Based on the petrographic analysis bentonite sample from Karangnunggal consists of an altered fragment of silica, mica, and montmorillonite in the matrix of volcanic glass. The texture of the sample is clastic with size in the range of $0.06-0.5 \mathrm{~mm}$. The sample is composed of $38 \%$ quartz, $46 \%$ montmorillonite, $13 \%$ halloysite, $2 \%$ volcanic glass, and $1 \%$ mica. The transformed mineral in which feldspar, quartz, and hornblende are interpreted as riolitic/dasitic, is shown in Figure 4

\section{Morphology Analysis}

Based on morphology and composition analysis through Scanning Electron Microscope (SEM) at a magnification of 500 times, shown in Figure 5 the bentonite sample from Karangnunggal is dominated by montmorillonite. The figure shows that the morphology of Karangnunggal bentonite is afan-shape, whereas halloysite is in the fine grain. The Karangnunggal bentonite was formed from tuff/ feldspathic through a hydrothermal process to form montmorillonite and halloysite minerals. 


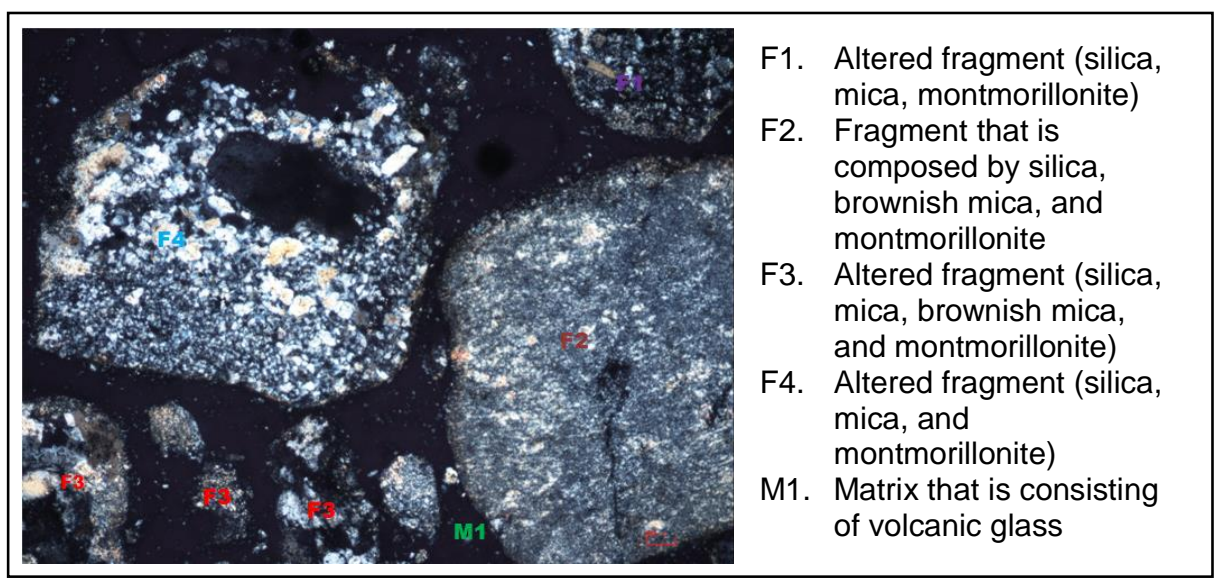

Figure 4. Petrographic analysis of bentonite sample from Karangnunggal

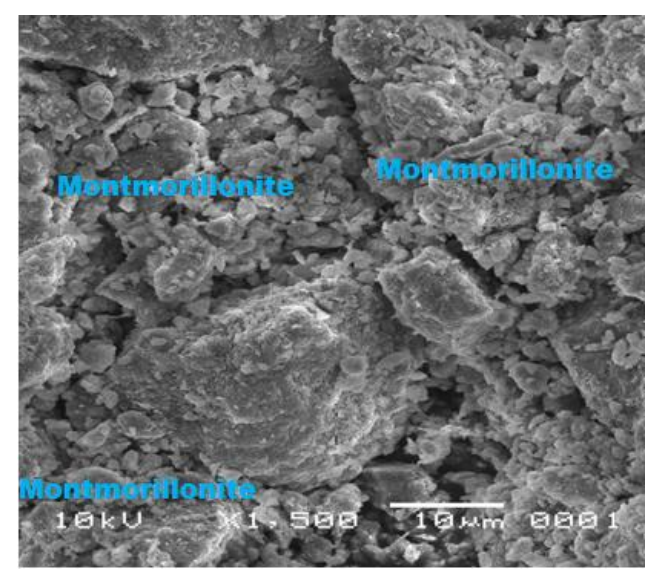

Figure 5. Morphology and compositional analysis of bentonite sample from Karangnunggal

\section{X-Ray Diffraction Analysis}

Result of XRD analysis is shown in Figure 6 . The figure shows that the Karangnunggal bentonite consists of montmorillonite, halloysite, and few amounts of magnetite. The calculation to the peaks that corresponds to each of those minerals shows that the sample is composed of 45 $\%$ montmorillonite, $39.30 \%$ quartz, $14.60 \%$ halloysite, and $0.70 \%$ magnetite. The mineral composition of this sample is shown in Table 2.

\section{Chemical Analysis}

The chemical analysis (Table 3 ) shows that the oxides within the bentonite from Karangnunggal are $\mathrm{SiO}_{2}(66.70 \%), \mathrm{Al}_{2} \mathrm{O}_{3}$ $(19.12 \%), \mathrm{Fe}_{2} \mathrm{O}_{3}(0.84 \%)$ and other minor oxide substances. $\mathrm{SiO}_{2}$ and $\mathrm{Al}_{2} \mathrm{O}_{3}$ are the main minerals needed as raw materials for ceramics production. On the other hand, $\mathrm{Fe}_{2} \mathrm{O}_{3}$ has a possible effect that can reduce the brightness of the ceramic (Celik, 2010).

The hardened grayish-white feldspar has been mined in the dispersion area 14.60 ha and fired at $1,400{ }^{\circ} \mathrm{C}$ by Jasmas Company, which results in the formation of homogenous bright grey glass liquid.

The greyish and brownish white kaolin consist of iron oxide, which is the result of tuff weathering of Genteng rock member of Jampang formation (Figure 2). The rock was split and fill a certain part of the valley. At $1,400{ }^{\circ} \mathrm{C}$, it shows that the glass has not yet been formed. The colors of the sample at $1,400{ }^{\circ} \mathrm{C}$ is red and brown with yellow spots. The samples (BC-1 and BC-2) that were fired at $1,200{ }^{\circ} \mathrm{C}$ can be seen in Figure 7. 


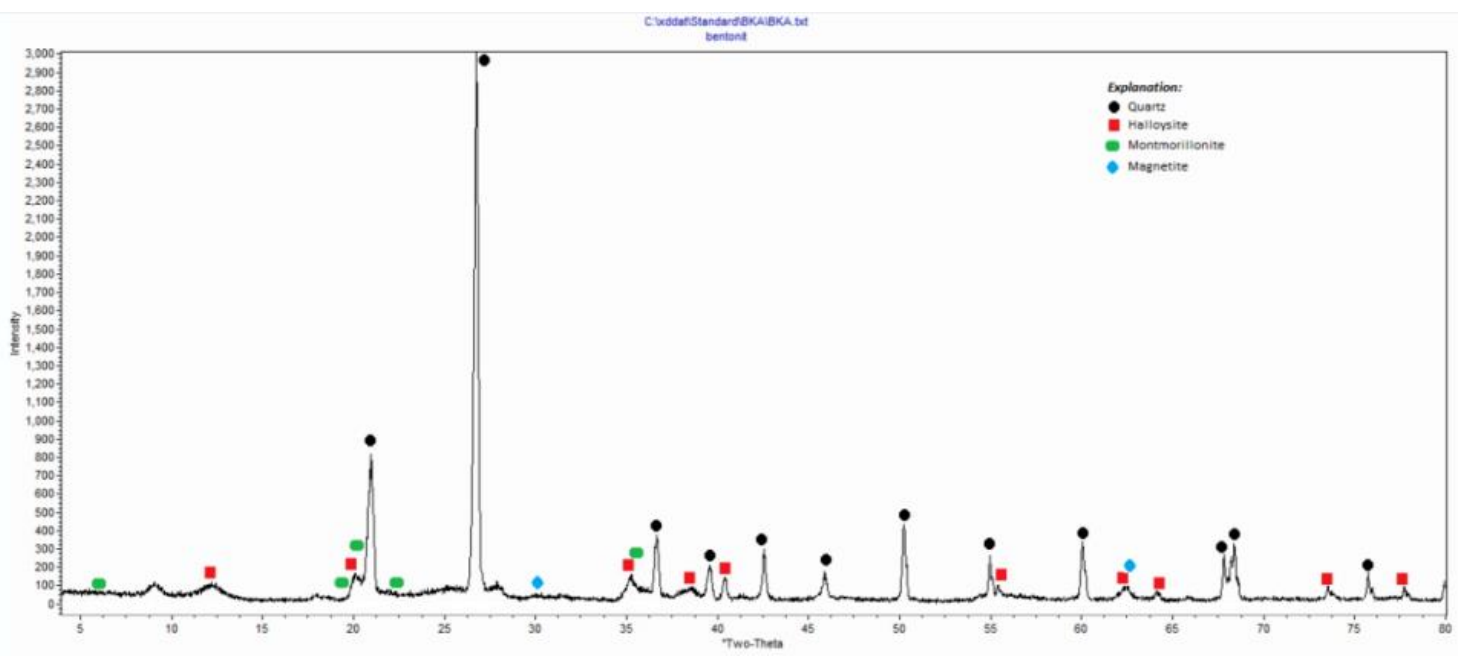

Figure 6. XRD diffractogram of Karangnunggal bentonite

Table 2. Mineral composition of Karangnunggal bentonite

\begin{tabular}{cccc}
\hline No & Mineral & Formula & Content (\%) \\
\hline 1 & Quartz & $\mathrm{SiO}_{2}$ & 39.30 \\
2 & Montmorillonite & $\mathrm{Al}_{2} \mathrm{O}_{3} 4 \mathrm{SiO}_{2} \mathrm{n} \mathrm{H}_{2} \mathrm{O}$ & 45.40 \\
3 & Halloysite & $\mathrm{Al}_{2} \mathrm{Si}_{2} \mathrm{O}_{5}(\mathrm{OH})_{4}$ & 14.60 \\
4 & Magnetite & $\mathrm{Fe}_{3} \mathrm{O}_{4}$ & 0.70 \\
\hline
\end{tabular}

Table 3. Chemical composition of raw material to make ceramics

\begin{tabular}{ccccc}
\hline \multirow{2}{*}{ Oxide } & \multicolumn{4}{c}{ Oxide content in the material (\%) } \\
\cline { 2 - 5 } & Bentonite & Kaolin & Feldspar & Silica Sand \\
\hline $\mathrm{SiO}_{2}$ & 71.22 & 71.82 & 75.05 & 88.85 \\
$\mathrm{Al}_{2} \mathrm{O}_{3}$ & 14.45 & 17.20 & 13.48 & 3.08 \\
$\mathrm{Fe}_{2} \mathrm{O}_{3}$ & 0.84 & 1.45 & 0.75 & 0.46 \\
$\mathrm{~K}_{2} \mathrm{O}$ & 1.02 & 0.75 & 2.88 & 0.80 \\
$\mathrm{Na}_{2} \mathrm{O}$ & 0.68 & 1.18 & 4.06 & 0.75 \\
$\mathrm{CaO}$ & 2.40 & 0.25 & 0.68 & 1.15 \\
$\mathrm{MgO}$ & 1.15 & 0.30 & 0.18 & 0.80 \\
$\mathrm{TiO}_{2}$ & 0.25 & 0.04 & 0.10 & - \\
$\mathrm{MnO}^{\mathrm{P} O} \mathrm{O}_{5}$ & 0.03 & 0.06 & 0.02 & 0.02 \\
$\mathrm{SO}_{3}$ & 0.14 & 0.62 & 0.08 & 0.04 \\
$\mathrm{LOI}$ & 0.22 & 0.45 & 0.20 & 0.24 \\
\end{tabular}

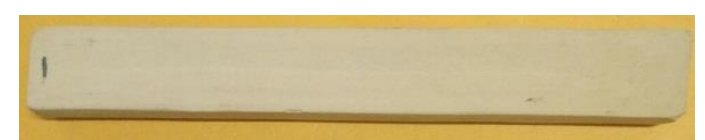

(a)

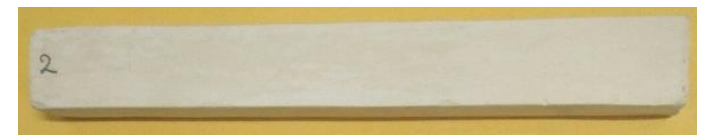

(b)

Figure 7. The samples (a) BC-1 and (b) BC-2, that were fired at $1,200^{\circ} \mathrm{C}$
Result of XRD analysis for samples with the code BC-1 and BC-2 is shown in Figure 8 and Figure 9. The figures show clearly that after being heated at $1200^{\circ} \mathrm{C}$, the mineral within the samples are dominated by quartz and mullite. Quartz possibly was resulted from two sources, silica sand and some parts of bentonite. Since the quartz is thermodynamically very stable, it did not undergo the reaction. The peak profiles of quartz in both samples are quite the same. 


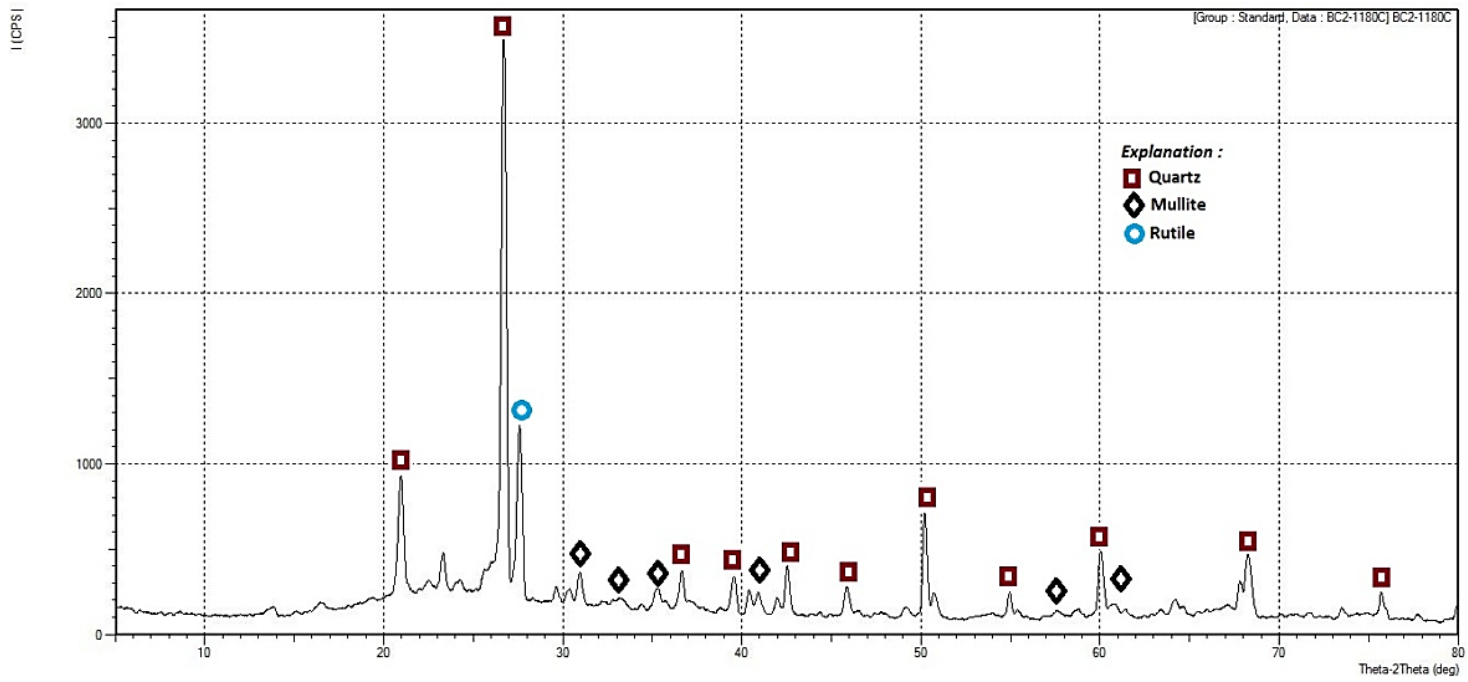

Figure 8. The XRD diffractogram of $B C-1$ sample that was fired at $1,200{ }^{\circ} \mathrm{C}$

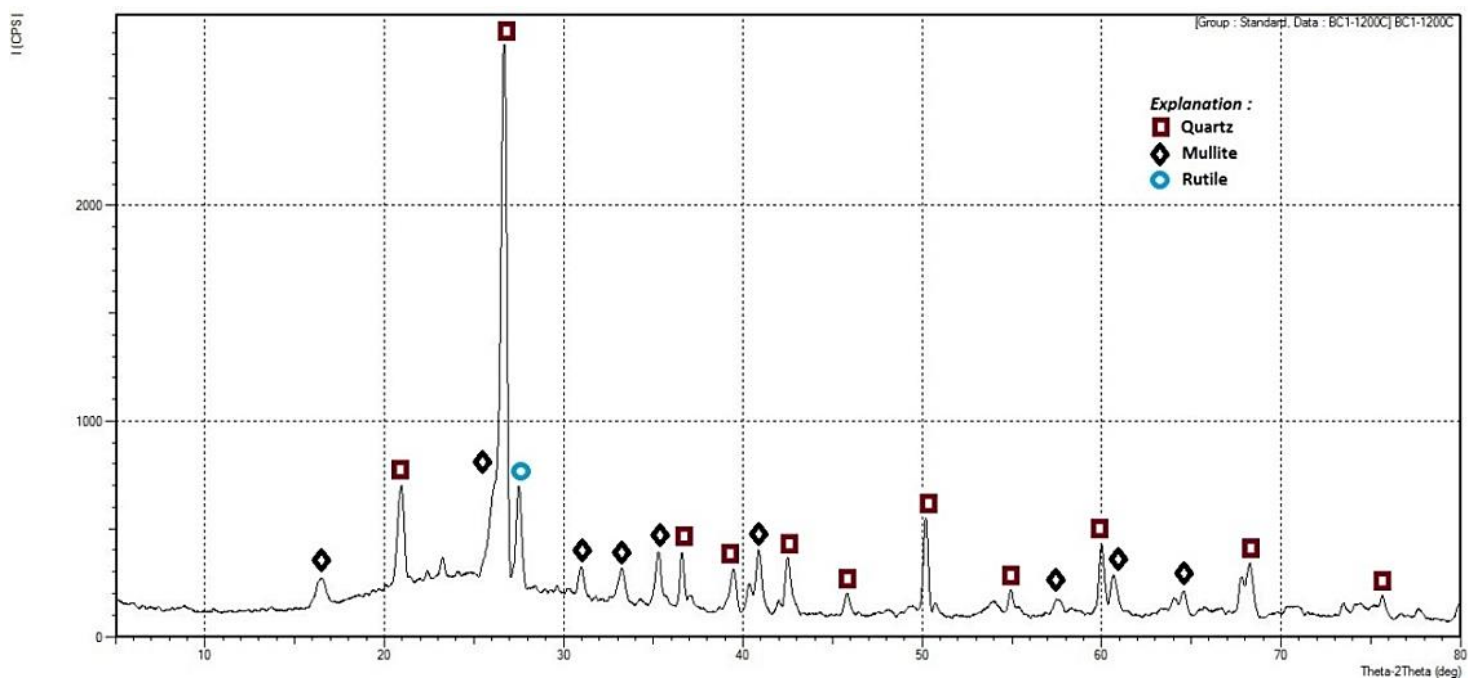

Figure 9. The XRD diffractogram of $\mathrm{BC}-2$ sample that was fired at $1,200{ }^{\circ} \mathrm{C}$

A brief study of the thermally treated bentonite (Zivica and Palou, 2015) has reported that bentonite converted to a microcrystalline variety of hydrous silica, with a general formula $\mathrm{SiOx} . \mathrm{H}_{2} \mathrm{O}$ after being heated at $650{ }^{\circ} \mathrm{C}$. The continuation of heating until $1200{ }^{\circ} \mathrm{C}$ removes $\mathrm{H}_{2} \mathrm{O}$ and leaving $\mathrm{SiO}_{2}$. Thus, the peaks correspond to $\mathrm{SiO}_{2}$ from samples $\mathrm{BC}-1$ and $\mathrm{BC}-2$ are possibly contributed by both silica sand and silica from the reacted bentonite.

Meanwhile, mullite $\left(3 \mathrm{Al}_{2} \mathrm{O}_{3} \cdot 2 \mathrm{SiO}_{2}\right)$ can be formed by the reaction of reactive alumina and reactive silica or the reaction of the minerals that contains $\mathrm{Al}-\mathrm{Si}-\mathrm{O}$, such as montmorillonite, kaolin or bentonite. The study on the thermochemical reaction of montmorillonite with other components has been reported in certain published papers. One of them are Ekosse and MulabaBafibiandi (2008) that has been suggested the reactions at high temperature that involved montmorillonite. The reaction can be written as follows.

$\mathrm{Na}(\mathrm{Al}, \mathrm{Mg})_{2} \mathrm{Si}_{4} \mathrm{O}_{10}(\mathrm{OH})_{2} \cdot \mathrm{H}_{2} \mathrm{O}$ (montmorillonite) + $\rightarrow 2 \mathrm{SiO}_{2}+2 \mathrm{NaAlSi}_{2} \mathrm{O}_{2}+\mathrm{CaAl}_{2} \mathrm{Si}_{2} \mathrm{O}_{8}+$ $2 \mathrm{MgAl}_{2} \mathrm{O}_{4}+4 \mathrm{H}_{2} \mathrm{O}$

$(\mathrm{Na}, \mathrm{Ca}) \mathrm{Al}_{2}\left(\mathrm{Al}_{2} \mathrm{Si}\right)_{4} \mathrm{O} 10(\mathrm{OH})_{2} \cdot \mathrm{H}_{2} \mathrm{O}$ (beidellite) + $\mathrm{SiO}_{2}$ (quartz) $+5 \mathrm{O}_{2} \rightarrow 2 \mathrm{SiO}_{2}+2 \mathrm{MgAl}_{2} \mathrm{O}_{4}+$ $2 \mathrm{NaAlSi}_{2} \mathrm{O}_{3}+\mathrm{CaAl}_{2} \mathrm{Si}_{2} \mathrm{O}_{2}$ 
It can be seen that montmorillonite can actually decompose to more simple compounds such as $\mathrm{MAISi}_{2} \mathrm{O}_{3}$ or $\mathrm{YAl}_{2} \mathrm{O}_{4}$ (where $\mathrm{M}=\mathrm{Na}$ or $\mathrm{Ca}, \mathrm{Y}=\mathrm{Mg}$ ). $\mathrm{XRD}$ analysis of the sample that was heated at $1200^{\circ} \mathrm{C}$ (shown in Figure 8 and Figure 9) shows that such components did not exist. The result of decomposition reaction of montmorillonite is a non-crystalline substance.

On the other hand, halloysite can also decompose to more simple components such as $\mathrm{xAl}_{2} \mathrm{O}_{3} \cdot \mathrm{ySiO}_{2}$. It is highly possible that mullite is the result of halloysite decomposition. The XRD patterns of heated samples (BC-1 and BC-2), that contain halloysite, supported this possibility. The reaction of halloysite decomposition can be written as follows (Zivica and Palou, 2015):

$3 \mathrm{Al}_{2} \mathrm{Si}_{2} \mathrm{O}_{5}(\mathrm{OH})_{4}$ (halloysite) $+4 \mathrm{O}_{2} \rightarrow$ $3 \mathrm{Al}_{2} \mathrm{O}_{3} \cdot 2 \mathrm{SiO}_{2}$ (mullite) $+4 \mathrm{SiO}_{2}+6 \mathrm{H}_{2} \mathrm{O}$

The mineral composition of samples (BC-1 and BC-2) is presented in Table 4 and Table 5. Table 4 show that at the addition of $10 \%$ bentonite, the mullite content increases whereas quartz content decreases. The chemical composition (Table 3) of bentonite is $\mathrm{Al}_{2} \mathrm{O}_{34} \mathrm{SiO}_{2} \mathrm{H}_{2} \mathrm{O}$, which is built by $\mathrm{Al}_{2} \mathrm{O}_{3}$ and $\mathrm{SiO}_{2}$ minerals. Meanwhile, kaolin also has $17.20 \% \mathrm{Al}_{2} \mathrm{O}_{3}$ and $71.82 \% \mathrm{SiO}_{2}$. The quartz and feldspar that were used in the experiment also have $88.85 \%$ and $75.05 \% \mathrm{SiO}_{2}$, respectively. The high content of $\mathrm{Al}_{2} \mathrm{O}_{3}$ and $\mathrm{SiO}_{2}$ in each raw material leads to the formation of newly minerals, mullite, and quartz, at $1,180^{\circ} \mathrm{C}$. The formation of these newly materials has also reported in a research work reported by Zivica and Palou (2015) during firing.
The increase of firing temperature until $1,200{ }^{\circ} \mathrm{C}$ increases mullite content (to become $52.90 \%$ ) and decreases the quartz content (down to $34.71 \%$ ).

Result of ceramics test after being fired at $1,200{ }^{\circ} \mathrm{C}$ is shown in Table 6 . The table shows that the absorption of water and the porosity decrease with the increase in firing temperature. It is caused by the increase of glass phase formation. The liquid phase contributes to the sintering process to increase the consolidation ability of the particles at high temperature. The optimum temperature that results in the maximum strength is at the level in which absorption of water is the lowest one. It is important to be noticed that the maximum strength can be obtained from the firing at the same temperature. The highest flexural strength (that is agree with the highest optimum density) is $254.70 \mathrm{~kg} / \mathrm{cm}^{2}$ at $10 \%$ bentonite and firing temperature $1,200{ }^{\circ} \mathrm{C}$.

According to Rasin and Hamad (2012), the heating of bentonite at $1,200-1,250{ }^{\circ} \mathrm{C}$ result in the increase of porosity. But, further heating at $1,300{ }^{\circ} \mathrm{C}$ decreases the porosity. The porosity decrease is caused by the lack of fluid phase that fills the void. The porosity decrease makes the fusion of the ceramic body and the formation of a glass phase take place. The formation of the glass phase contributes to the decrease of open pores in the ceramic. This phase aids sintering takes place. Fast sintering causes an increase in thermal flexure up to $254.70 \mathrm{~kg} / \mathrm{cm}^{2}$ and a decrease in water absorption to $3.98 \%$.

Table 4. Mineral composition of $\mathrm{BC}-1$ sample that was fired at $1,200{ }^{\circ} \mathrm{C}$

\begin{tabular}{cccc}
\hline No & Mineral & Formula & Content (\%) \\
\hline 1 & Quartz & $\mathrm{SiO}_{2}$ & 43.60 \\
2 & Mullite & $\mathrm{Al}_{2} \mathrm{O}_{3} \mathrm{SiO}_{2}$ & 38.30 \\
3 & Rutile & $\mathrm{TiO}_{2}$ & 18.10 \\
\hline
\end{tabular}

Table 5. Mineral composition of $\mathrm{BC}-2$ sample that was fired at $1,200^{\circ} \mathrm{C}$

\begin{tabular}{cccc}
\hline No & Mineral & Formula & Content (\%) \\
\hline 1 & Quartz & $\mathrm{SiO}_{2}$ & 34.70 \\
2 & Mullite & $\mathrm{Al}_{2} \mathrm{O}_{3} \mathrm{SiO}_{2}$ & 52.90 \\
3 & Rutile & $\mathrm{TiO}_{2}$ & 12.50 \\
\hline
\end{tabular}


Table 6. Result of ceramics test after being fired at $1,200^{\circ} \mathrm{C}$

\begin{tabular}{cccccc}
\hline $\begin{array}{c}\text { Sample } \\
\text { Code }\end{array}$ & $\begin{array}{c}\text { Dry } \\
\text { Shrinkage } \\
(\%)\end{array}$ & $\begin{array}{c}\text { Firing Shrinkage } \\
(\%)\end{array}$ & $\begin{array}{c}\text { Dry Flexural } \\
\text { Strength }\left(\mathrm{kg} / \mathrm{cm}^{2}\right)\end{array}$ & $\begin{array}{c}\text { Thermal Flexural } \\
\text { Strength } \\
\left(\mathrm{kg} / \mathrm{cm}^{2}\right)\end{array}$ & $\begin{array}{c}\text { Water } \\
\text { Absorption } \\
(\%)\end{array}$ \\
\hline BC-0 & 5.29 & 3.84 & 36.85 & 218.85 & 4.72 \\
BC-1 & 5.81 & 4.15 & 39.70 & 237.49 & 4.43 \\
BC-2 & 6.17 & 4.47 & 42.16 & 254.70 & 3.98 \\
BC-3 & 6.24 & 5.06 & 43.58 & 251.96 & 3.87 \\
\hline
\end{tabular}

\section{CONCLUSIONS}

- Based on the chemical and physical characterization, the property of Karangnunggal bentonite, bentonite can be used as an additive material to produce high strength ceramics.

- The maximum flexural strength that can be achieved is $254.70 \mathrm{~kg} / \mathrm{cm}^{2}$ at $10 \%$ bentonite and $1,200{ }^{\circ} \mathrm{C}$ combustion temperature.

- The experimental result showed that the formulation $55 \%$ kaolin, $20 \%$ quartz, 15 $\%$ feldspar, and $10 \%$ bentonite had the highest flexure and the lowest moisture absorption of both were $254.70 \mathrm{~kg} / \mathrm{cm}^{2}$ and $3.98 \%$, respectively.

\section{ACKNOWLEDGEMENTS}

The authors would like to express the gratitude to the Research Center for Geotechnology and Center for Ceramics to allow the authors for using the equipment in both centers. We also would like to thank to Ir. Sri Indarto for his valuable suggestion.

\section{REFERENCES}

Boch, P. and Niepce, J.-C. (2007) Ceramic materials: Processes, properties and applications. Edited by P. Boch and Jean-Claude Niepce. London, UK: ISTE. doi: 10.1002/9780470612415.

Boussak, H., Chemani, H. and Aicha, S. (2015) 'Characterization of porcelain tableware formulation containing bentonite clay', International Journal of Physical Sciences, 10(1), pp. 38-45. doi: $10.5897 /$ IJPS2014.4218.

Celik, H. (2010) 'Technological characterization and industrial application of two Turkish clays for the ceramic industry', Applied Clay Science, 50(2), pp. 245-254. doi: 10.1016/j.clay.2010.08.005.
Djambazov, S. P., Yoleva, A. P. and Malinov, O. K. (2009) 'Red firing ceramic bodies for clinker tiles and bricks', pp. 8-10.

Ekosse, G.-I. E. and Mulaba-Bafibiandi, A. F. (2008) 'Mineral thermochemistry of bentonite and kaolin related to their possible application in the ceramic industry', Journal of Applied Sciences, 8(22), pp. 4145-4151. doi: $10.3923 / j a s .2008 .4145 .4151$.

Gualtieri, A. F. (2007) 'Thermal behavior of the raw materials forming porcelain stoneware mixtures by combined optical and in situ X-Ray dilatometry', Journal of the American Ceramic Society, 90(4), pp. 1222-1231. doi: 10.1111/j.1551-2916.2007.01614.x.

Hosten, C. and Cimilli, H. (2009) 'The effects of feed size distribution on confined-bed comminution of quartz and calcite in piston-die press', International Journal of Mineral Processing, 91(3-4), pp. 8187. doi: 10.1016/j.minpro.2009.01.002.

Liu, H., Xie, B. and Qin, Y. (2017) 'Effect of bentonite on the pelleting properties of iron concentrate', Journal of Chemistry, 2017, pp. 1-6. doi: $10.1155 / 2017 / 7639326$.

Rasin, F. A. and Hamad, E. A. (2012) 'Effect of adding Mgo \& Al2O3 on ceramic body prepared from Iraqi activated bentonite', British Journal of Science, 7(2), pp. 5663. Available at: http://www.ajournal.co.uk/pdfs/BSvolum e7(2)/BSVol.7 (2) Article 7.pdf.

Rowe, R. C., Sheskey, P. J. and Quinn, M. E. (eds) (2009) 'Bentonite', in Handbook of Pharmaceutical Excipient. 6th Ed. Pharmaceutical Press, pp. 53-55.

Savic-Gajic, I. M., Savic, I. M., Stojiljkovic, S. T. and Gajic, D. (2014) 'Industrial application of clays and clay minerals', in Wesley, L. R. (ed.) Clays and Clay Minerals: Geological Origin, Mechanical Properties and Industrial Applications. Nova Science Publishers, pp. 379-402. 
Savic, I. M., Stojiljkovic, S. T., Savic, I. M., Stojanovic, S. B. and Moder, K. (2012) 'Modeling and optimization of $\mathrm{Fe}(\mathrm{III})$ adsorption from water using bentonite clay: Comparison of central composite design and artificial neural network', Chemical Engineering \& Technology, 35(11), pp. 2007-2014.

doi: 10.1002/ceat.201200085.

Savic, Ivana M., Savic, Ivan M., Stojiljkovic, S. T. and Gajic, D. G. (2014) 'Modeling and optimization of energy-efficient procedures for removing lead(II) and zinc(II) ions from aqueous solutions using the central composite design', Energy, 77, pp. 66-72.

doi: 10.1016/j.energy.2014.04.088.
Septawendar, R., Nuryanto and Subari (2007) 'Karakterisasi tanah liat Tanjung Beringin, Sumatera Utara dan pemanfaatannya untuk badan keramik stoneware', Jurnal Keramik dan Gelas Indonesia, 16(1), pp. 26-35.

Supriatna, S., Sarmili, L., Sudana and Koswara, A. (1992) 'Geological map of the Karangnunggal quadrangle (Jawa, scale 1:100.000)'. Bandung: Geological Research and Development Centre, p. 1.

Zivica, V. and Palou, M. T. (2015) 'Physicochemical characterization of thermally treated bentonite', Composites Part B: Engineering, 68, pp. 436-445. doi: 10.1016/j.compositesb.2014.07.019. 